\title{
Sequence-dependent Kinetic Behavior of Protein-induced B- to Z-DNA Transition
}

\author{
Dong Van Quyen, ${ }^{\dagger}$ Keong Kyu Kim, ${ }^{\dagger, 4, *}$ and Yang-Gyun Kim ${ }^{\text {s.* }}$ \\ 'Department of Molecular Cell Biology, Samstung Biomedical Research Institute, Sungknthkwan University School of Medicine, \\ Suwon 440-746, Korea. "E-mail: kkim(med.skkti.ac.kr \\ ${ }^{*}$ Stingkytmkwan Advanced Institute of Nanotechnology, Stingkyunkwan Universiry, Strwon 440-746, Korea

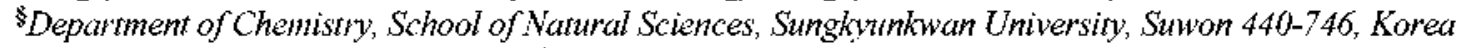 \\ ${ }^{*}$ E-mail:ygkimmir@skku.edt \\ Received May 8, 2006
}

Key Words : Z-DNA, BZ transition, Sequence-dependency

\begin{abstract}
Z-DNA is a left-handed duplex DNA that contains a zigzag backbone. However, Z-DNA is merely not a mirrorimage of the right-handed B-DNA. Since the first crystal structure of Z-DNA was revealed, ${ }^{1}$ there have been many studies about chemical and physical characteristics of ZDNA. It is well known that Z-DNA formation has a preference for sequences with altemating pyrimidine/purine (APP), especially altemating $\mathrm{dC}$ and $\mathrm{dG}^{2}$ Poly $\mathrm{d}(\mathrm{GC})$ can be stabilized in $\mathrm{Z}$ conformation in the presence of salts such as $4 \mathrm{M} \mathrm{NaCl}^{3}$ In addition, positively charged molecules such as spermine and cobalt hexaamine can facilitate $\mathrm{B}-\mathrm{Z}$ transition of double stranded DNA (dsDNA) into $Z$ conformation. ${ }^{2}$ Chemical modifications on bases also stabilize dsDNA in $Z$ conformation; for instance, poly $d\left(G^{\text {smee }} \mathrm{C}\right)$ requires much lower salt concentrations to form $Z$-DNA than those used for poly $\mathrm{d}(\mathrm{GC}) .^{2} I n v$ wo, it is thought that negative supercoiling occurring from various biological processes such as RNA transcription is a major driving force to stabilize Z-DNA. ${ }^{4}$ Recently, a novel Z-DNA binding motif $\mathrm{Z} \alpha$ was discovered by Rich group: "The $\mathrm{Z} \alpha$ was first identified from human ADAR1 (double-stranded RNA adenosine deaminase 1$)^{5}$; an RNA editing enzyme that is responsible for A-to-I RNA editing by deaminating adenosine. Thus, human $\mathrm{Z} \alpha$ from $\mathrm{ADAR} 1$ (hZ $\alpha_{\mathrm{ADAR} 1}$ ) has been a subject of works about both its Z-DNA binding activity and its use for Z-DNA study. ${ }^{6}$
\end{abstract}

It is suggested that Z-DNA might have a functional role in transcription from the work of $\mathrm{Ho}$ and his colleagues, ${ }^{7}$ in which Z-forming sequences are widely found near transcription start sites. In addition, the recent study by Liu $e t a l$ also demonstrated that Z-DNA formation is necessary for the transcription initiation of the CSFI (colony stimulating factor 1) gene. ${ }^{8}$ Thus, understanding B-Z transition mechanism of dsDNA would help to elucidate the role of Z-DNA as a potential modulator of eukaryotic transcription in vivo.

$\mathrm{B}-Z$ transition can be achieved in the presence of high-salt or Z-DNA binding protein, Z $\alpha$. Salt-induced B-Z transition is well-established in terms of chemical equilibrium. In kinetic aspect, there are two models to explain how B-Z transition undergoes in the presence of Z-DNA inducers. The all-or-none model proposed by Pohl and Jovin ${ }^{3}$ assumes that Z-forming nucleation events taking place only at the ends of polymer: On the other hand, the model of Walker and Aboul-ela ${ }^{9}$ suggested that nucleation events occur at partially open or distorted base pair regions within the Bform DNA. The well-designed study by Perez $e t a l^{10}$ demonstrated the existence of a salt threshold in B-Z transition. A pathway of $B-Z$ transition mechanism depends on whether the salt concentration is higher or lower than the threshold. On the other hand, so far there is almost no study available about kinetic behaviors of $\mathrm{B}-\mathrm{Z}$ transition induced by $h Z \alpha_{\text {ADARI. }}$.

Our approach to study B-Z transition mechanism is to utilize $\mathrm{hZ} \alpha_{\mathrm{ADAR} 1}$ as a Z-DNA inducer. In the co-crystal structure of $h Z \alpha_{A D A R I}: Z-D N A,{ }^{11} h Z \alpha_{A D A R}$ specifically interacts with phosphate backbones of Z-DNA, which explains why $\mathrm{hZ} \alpha_{\mathrm{ADARI}}$ binds to Z-DNA specifically and tightly. $\mathrm{hZ} \alpha_{\mathrm{ADAR} 1}$ is a powerful agent to induce/stabilize $Z$ conformation in dsDNA so that it is able to flip many different sequences of DNA other than $\mathrm{d}(\mathrm{CG})$ repeats in low salt condition. ${ }^{12} \mathrm{Z}$ DNA has been thought to be formed in sequences composed of d(CA/TG) repeats. However, it is energetically much less favorable to form Z-DNA. Only under extreme salt conditions, poly d(AC/GT) is also able to adopt $Z$ conformation in vitro. ${ }^{13}$ In this study, taking advantage of $h Z \alpha_{\mathrm{ADAR} 1}$ as a powerful Z-DNA inducer, B-Z transitions of DNAs containing $d(C A / T G)$ repeats as well as $d(C G)$ repeats were investigated.

B-Z transitions of DNAs with different sequence compositions of $d(C G)$ repeats and $d(C A T G)$ repeats were studied by using circular dichroism (CD). Table 1 summarized dsDNA substrates used for this study. First, fourteen base pair dsDNA substrates in different $d(C G)$ and d(CATG) contents were designed to compare the rates of $\mathrm{B}-\mathrm{Z}$ transition induced by $\mathrm{hZ} \alpha_{\mathrm{ADAR} 1}, \mathrm{CG} 7$ and $\mathrm{CA} 7$ have seven repeats of $d(C G)$ and $d(C A / T G)$, respectively, while CACG7 has a mixed sequence containing three $d(C G)$ repeats and four $\mathrm{d}(\mathrm{CA} / \mathrm{TG})$ repeats, i.e. $\mathrm{d}(\mathrm{CACGCACGCACGCA}$ TGCGTGCGTGCGTG). Based on thermodynamic stability for dinucleotide base pairs in Z-DNA calculated by Kagawa et al. ${ }^{14}$ the d(CA/TG) base pair is energetically less favorable to be stabilized in $Z$ conformation than $d(C G)$. Thus, the order of DNA substrates energetically favorable for ZDNA formation would be $\mathrm{CG} 7>\mathrm{CACG} 7>\mathrm{CA} 7$. 
Table 1. Sequences of DNA substrates used for B-Z transition in this study

\begin{tabular}{cc}
\hline Name & \multicolumn{1}{c}{ Sequence } \\
\hline CA7 & 5'-CACACACACACACA-3' \\
& 3'-GTGTGTGTGTGTGT-5' \\
CACG7 & 5'-CACGCACGCACGCA-3' \\
& $3^{+}$-GTGCGTGCGTGCGT-5' \\
CG7 & $5^{+}$-CGCGCGCGCGCGCG-3' \\
& 3'-GCGCGCGCGCGCGC-5' \\
\hline
\end{tabular}

In the physiological condition with a low salt concentration (10 mM HEPES, pH 7.4, $10 \mathrm{mM} \mathrm{NaCl}$ ), CD spectra between $240 \mathrm{~nm}$ and $310 \mathrm{~nm}$ were taken to detect $\mathrm{B}-\mathrm{Z}$ transitions of dsDNA substrates by $h Z \alpha_{A D A R}$. For kinetic study, changes of the $\mathrm{CD}$ signals at $255 \mathrm{~nm}$ were recorded for $40 \mathrm{~min}$ after adding $\mathrm{hZ} \alpha_{\mathrm{ADAR} 1}$. Various temperatures ranging from $5^{\circ} \mathrm{C}$ to $25^{\circ} \mathrm{C}$ were used for each reaction. Figure 1 showed that $\mathrm{hZ} \alpha_{\text {ADARI }}$ stabilized all dsDNA oligomers (CG7, $C A 7, C A C G 7)$ into $Z$ conformation. The rates of $\mathrm{B}-\mathrm{Z}$ transition monitored at $255 \mathrm{~nm}$ showed a dependency on $\mathrm{d}(\mathrm{CG})$ dinucleotide content in the substrate DNAs (Fig. 2). Surprisingly $\mathrm{CA} 7$ had the fastest flipping rate among three substrates regardless of temperature (Fig. 2D). Next we carried out $\mathrm{B}-\mathrm{Z}$ transition of poly $\mathrm{d}(\mathrm{CG})$ and poly $\mathrm{d}(\mathrm{AC} / \mathrm{GT})$ induced by $\mathrm{hZ} \alpha_{\mathrm{ADAR} 1}$ to check the effect of polymer length on flipping rate. As shown in Figure 3, the B-Z transition of poly $\mathrm{d}(\mathrm{AC} / \mathrm{GT})$ was still faster than that of poly $\mathrm{d}(\mathrm{GC})$ in the presence of $h Z \alpha_{A D A R I}$. Thus, $h Z \alpha_{A D A R 1}$ induced $\mathrm{B}-\mathrm{Z}$ transition has a dependency on sequence context, not on polymer length.

Our result clearly demonstrated that $\mathrm{hZ} \alpha_{\mathrm{ADARI}}$ can induce Z-DNA formation in these dsDNAs. However, at the present stage, we do not know how B-Z transition mechanism by $\mathrm{hZ} \alpha_{\mathrm{ADAR} 1}$ occurs in detail. Nevertheless, it is possible that there are two pathways to shift $\mathrm{B}-\mathrm{Z}$ equilibrium of dsDNA by $h Z \alpha_{A D A R I}$. Firstly, $h Z \alpha_{\text {ADARI }}$ only interacts with $Z$ conformation of DNA within DNA substrates. Small amounts of
Z-DNA always exist as DNA stays in the B-Z equilibrium. When $\mathrm{hZ} \alpha_{\mathrm{ADARI}}$ binds to $\mathrm{Z}$-DNA, hZ $\alpha_{\mathrm{ADARI}}$-bound $\mathrm{Z}$ DNAs are sequestered from the rest of the B-Z equilibrium. Consequently, thus, apparent $B-Z$ equilibrium moves toward Z-DNA by accumulating $\mathrm{hZ} \alpha_{\mathrm{ADAR}} \mathrm{Z}$ Z-DNA complexes in the reaction. Secondly, $h Z \alpha_{A D A R 1}$ may actively engage with DNAs to convert B-DNA into Z-DNA. When hZ $\alpha_{\mathrm{ADAR}}$ collides with DNA, this collision may stimulate formation of Z-DNA and it results in formation of $\mathrm{hZ} \alpha_{\mathrm{ADARI}}: Z$-DNA complex. Inverse relationship between stabilities of DNA sequences in Z-DNA and their flipping rates by $\mathrm{hZ} \alpha_{\mathrm{ADAR} 1}$ indicates that $\mathrm{hZ} \alpha_{\mathrm{ADAR} 1}$ may actively shift $\mathrm{B}-\mathrm{Z}$ equilibrium toward Z-DNA. Overall, our result implies that the rate of flipping by $\mathrm{hZ} \alpha_{\mathrm{ADAR}}$ is dependent on strength of basepairings on DNA track, which in turn $h Z \alpha_{\mathrm{ADAR} 1}$ could readily switch the backbone of DNA into $Z$ conformation.

Since our kinetic study demonstrates that the flipping rates of dsDNAs by $h Z \alpha_{\mathrm{ADAR} 1}$ were inversely related to strength of base pairings within dsDNAs. This observation implies that a crucial step for $\mathrm{B}-\mathrm{Z}$ transition induced by $\mathrm{hZ} \alpha_{\mathrm{ADAR} 1}$ may need strand separation or breakage of base pair events. In this pathway, encounters between DNA and $h Z \alpha_{\mathrm{ADAR}}$ in the reaction may be important for the rates of $\mathrm{B}-\mathrm{Z}$ transition. When $\mathrm{hZ} \alpha_{\mathrm{ADARI}}$ collides with $\mathrm{DNA}, \mathrm{hZ} \alpha_{\mathrm{ADARI}}$ may rearrange DNA backbones into $Z$ conformation. This could occur more readily if strength of base-pairing is weaker to break, which explains why B-Z transition of DNA containing high content of AT base pair is faster.

In summary, our study demonstrated that $\mathrm{B}-\mathrm{Z}$ transition induced by $\mathrm{hZ} \alpha_{\mathrm{ADARI}}$ behaves quite unexpectedly. When $\mathrm{hZ} \alpha_{\mathrm{ADARI}}$ works as a powerful Z-DNA inducer, it stimulates Z-DNA formation by the mechanism that depends on the strength of base-pairings in DNA substrates. Consequently, the weaker base-pairing within DNA track results in the faster $\mathrm{B}-\mathrm{Z}$ transition induced by $\mathrm{hZ} \alpha_{\mathrm{ADARI}}$. Finally, our work extends the scope of $Z$-DNA study by using $h Z \alpha_{\text {ADARI }}$ as a Z-DNA inducer. Many different sequences of dsDNAs that
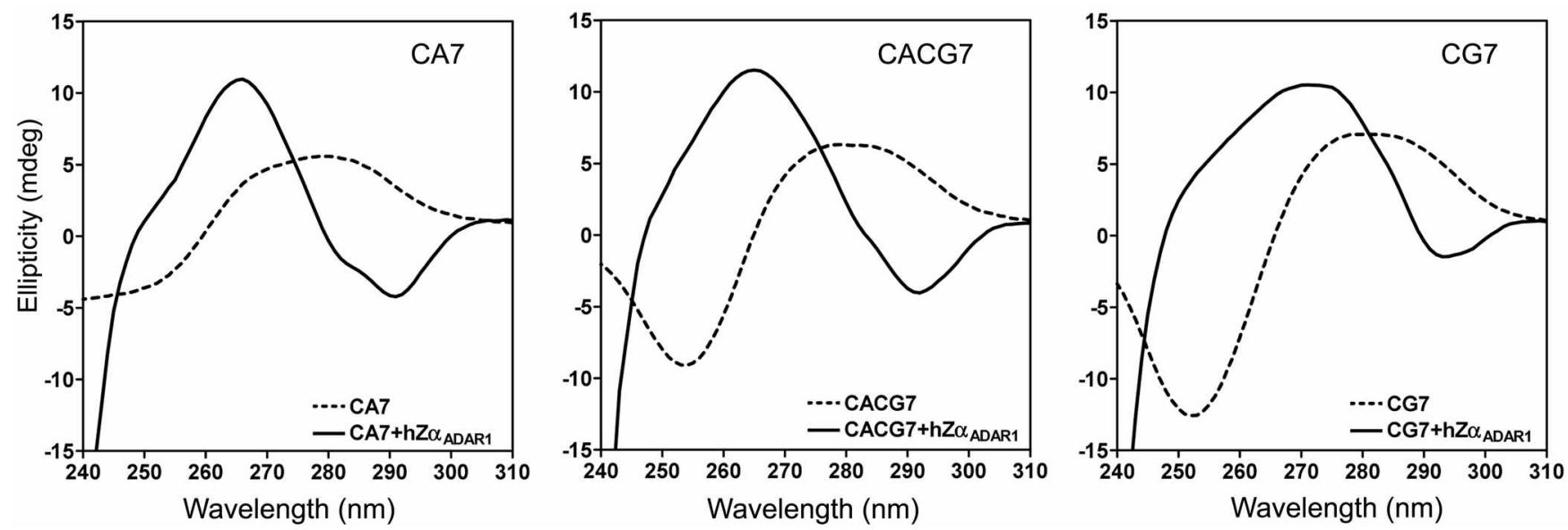

Figure 1. CD spectra of the reaction mixtures after I hr. CD spectra of reactions with three different DNA substrates at $25^{\circ} \mathrm{C}$ were obtained before adding $\mathrm{hZ} \alpha_{\mathrm{ADAR}}$ (dotted line) and in the presence of $\mathrm{hZ} \alpha_{\mathrm{ADAR}}$ (solid line) after $1 \mathrm{hr}$ incubation, respectively. All DNA samples showed typical B-DNA spectra, while spectral changes to Z-DNA were observed as $h Z \alpha_{A D A}$, was added. Inversion of the CD spectrum arounds $255 \mathrm{~nm}$ and $292 \mathrm{~nm}$ is a typical characteristic of $\mathrm{B}-\mathrm{Z}$ transition. 
(A)

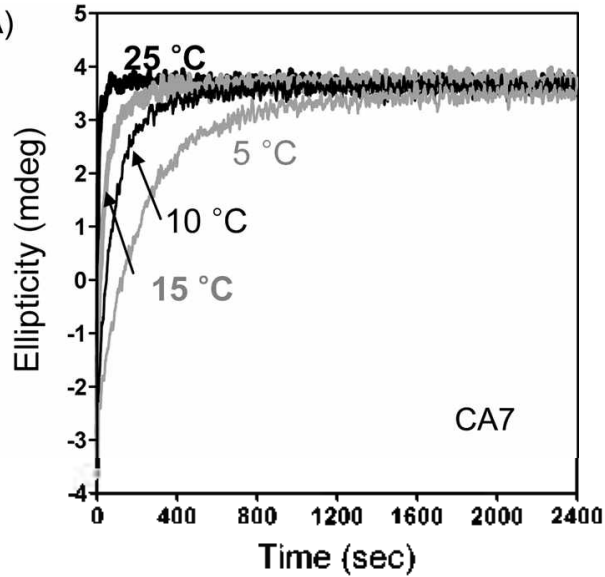

(C)

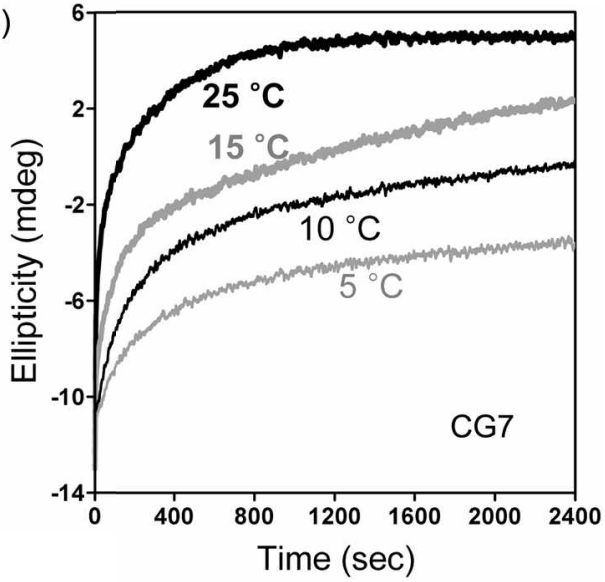

(B)

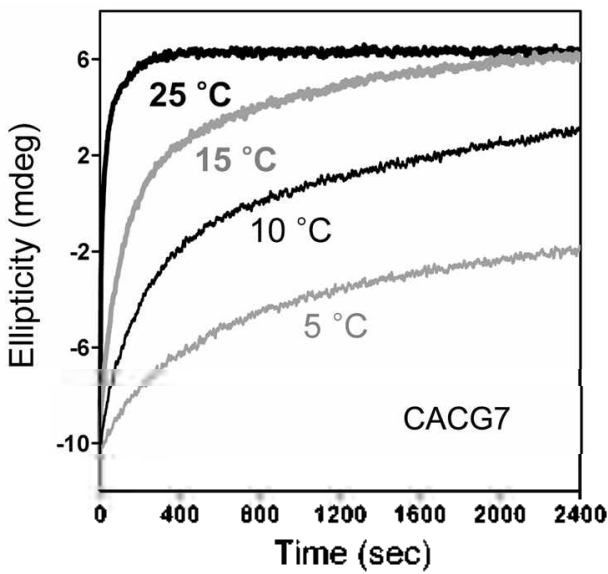

(D)

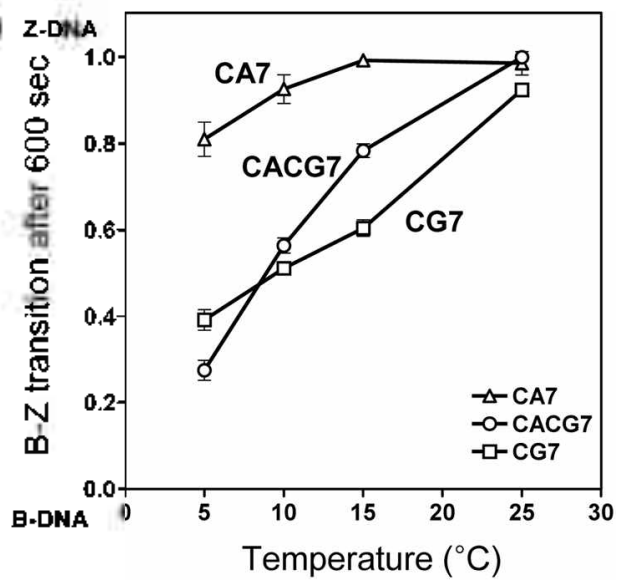

Figure 2. Temperature-dependence of the $\mathrm{h} Z \alpha_{\mathrm{ADARI}}$ induced $\mathrm{B}-\mathrm{Z}$ transition. Time-dependent change at $255 \mathrm{~nm}$ in the $\mathrm{CD}$ spectrum was monitored to determine degree of $\mathrm{B}-\mathrm{Z}$ transition. To check temperature-dependence of the $\mathrm{hZ} \alpha_{\mathrm{A} D \mathrm{~A} \text { r }}$-induced $\mathrm{B}-\mathrm{Z}$ transition, $\mathrm{CD}$ signal changes at $255 \mathrm{nin}$ for $(\Lambda) \mathrm{C} \Lambda 7,(B) \mathrm{CACG7}$, (C) $\mathrm{CG} 7$ were collected at four different temperatures, $5^{\circ} \mathrm{C}, 10^{\circ} \mathrm{C}, 15^{\circ} \mathrm{C}$ and $25^{\circ} \mathrm{C}$. $\Lambda \mathrm{s}$

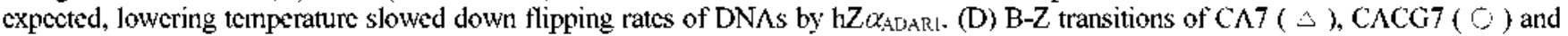
CG7 $(\square)$ induced by $\mathrm{hZ} \alpha_{\mathrm{A} D A R}$ were compared after $600 \mathrm{sec}$. The degree of B-Z transition was normalized as a scale 0 to 1 ; B-DNA only in the reaction is as 0 and the complete conversion to Z-DNA is as 1. CA7 showed the fastest flipping rate at all temperatures. CG7 has slower flipping rates than those of $\mathrm{C} \Lambda \mathrm{CG} 7 \mathrm{except} 5^{\circ} \mathrm{C}$.

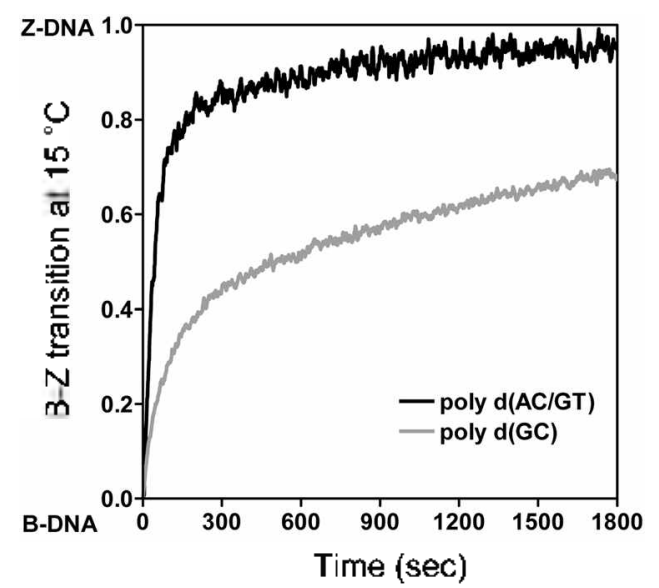

Figure 3. Comparison of B-Z transition kinetics between polymers. The effect of DNA polymer length on the $h Z \alpha_{A D A R I}-$ induced $\mathrm{B}-\mathrm{Z}$ transition was investigated by comparing poly $\mathrm{d}(\mathrm{GC})$ and poly $\mathrm{d}(\mathrm{AC} / \mathrm{GT})$ at $15^{\circ} \mathrm{C}$. The degrees of $\mathrm{B}-\mathrm{Z}$ transition were normalized as a scale 0 to 1 . The result showed that the $\mathrm{B}-\mathrm{Z}$ transition of poly $\mathrm{d}(\Lambda \mathrm{C} / \mathrm{GT})$ is faster than poly $\mathrm{d}(\mathrm{GC})$, which confinned that $\mathrm{hZ} \alpha_{\mathrm{ADARI}}$-induced $\mathrm{B}-\mathrm{Z}$ transition is dependent on sequence context. do not easily form $Z$ conformation could be studied by their $\mathrm{Z}-\mathrm{DNA}$ formation using $\mathrm{hZ} \alpha_{\mathrm{ADAR} 1}$.

\section{Experimental Section}

Protein and DNA preparation. $\mathrm{h} Z \alpha_{\mathrm{ADAR}}$ peptide was expressed and purified as described previously. ${ }^{6}$ Briefly, the $\mathrm{Z} \alpha$ domain gene from human ADAR1 was cloned into pET28a expression vector. $h Z \alpha_{\text {ADAR } 1}$ with the N-terminal His-tag was expressed in $E$. coll and purified by affinity purification using a His-affinity column (Amersham Biosciences). After thrombin digestion to remove the $\mathrm{N}$-terminal His-tag, $\mathrm{hZ} \alpha_{\mathrm{ADAR} 1}$ peptides were then further purified to homogeneity with a Hi-Trap SP column (Amersham Biosciences). The $\mathrm{hZ} \alpha_{\mathrm{ADAR} 1}$ peptide was then dialyzed against buffer A $(5 \mathrm{mM}$ HEPES, $\mathrm{pH} 7.5,10 \mathrm{mM} \mathrm{NaCl})$, and concentrated to $>1 \mathrm{mM}$.

DNA oligonucleotides were synthesized and purified by HPLC. DNAs were dissolved in buffer $\mathrm{B}(10 \mathrm{mM}$ Tris- $\mathrm{Cl}$, $\mathrm{pH} 7.4,50 \mathrm{mM} \mathrm{NaCl}, 0.1 \mathrm{mM}$ EDTA) prior to annealing to form duplex DNAs. Annealing of DNA oligomers 
was achieved by heating DNA samples at $90{ }^{\circ} \mathrm{C}$ for $3 \mathrm{~min}$ and slowly cooled down to $4^{\circ} \mathrm{C}$. Polymer DNAs were purchased from Amersham and dissolved in Buffer B prior to use.

CD measurement. Measurements were taken on $30 \mathrm{~kg} /$ $\mu \mathrm{L}$ ( $45 \mu \mathrm{M}$ in base pair) of DNA in $2 \mathrm{~mL}$ of CD buffer (10 $\mathrm{mM}$ HEPES, $\mathrm{pH} 7.4,10 \mathrm{mM} \mathrm{NaCl}, 0.1 \mathrm{mM}$ EDTA) in a 1 $\mathrm{cm}$ quartz cell. $\mathrm{CD}$ spectra were taken at various temperatures using a J-810 CD spectrometer (Jasco, Japan). hZ $\alpha_{\text {ADARI }}$ peptide was added to the sample in the final concentration of $20 \mu \mathrm{M}$ from a concentrated stock solution, not exceeding $5 \%$ of the total volume. After $1 \mathrm{hr}$ incubation, CD spectra of the reaction mixtures were then recorded between $240 \mathrm{~nm}$ to $310 \mathrm{~nm}$ at $1 \mathrm{~nm}$ intervals averaged over $3 \mathrm{sec}$. For kinetic profiles of the $\mathrm{B}-\mathrm{Z}$ transition, time-dependent change of $\mathrm{CD}$ spectrum at $255 \mathrm{~nm}$ was monitored to measure the rate of B$\mathrm{Z}$ transition induced by $\mathrm{hZ} \alpha_{\mathrm{ADARI}}$. For this measurement, $\mathrm{CD}$ signal changes at $255 \mathrm{~nm}$ were collected at $1-\mathrm{sec}$ intervals after a 5 -sec dead time.

Acknowledgment. This work was supported from the National Research Laboratory program of the Korea Ministry of Science and Technology (NRL-2006-02287).

\section{References}

1. Wang, A. H. J.; Quigley, G. J.; Kolpak, F. J.; Crawford, J. I.; van Boom, J. H.; van der Marel, G.; Rich, A. Noture 1979, 282, 680.

2. Rich, A.; Nordheim, A.; Wang. A. H. J. Anmt. Rev, Biochent. $1984,53,791$,

3. Pohl, F. M.; Jovin, T. M. J. Mol. Biol. 1972, 67, 375.

4. Peck, L. J.; Nordheim, A.; Rich, A.; Wang, J. C. Proc. Natl. Acad.
Sci, USA 1982, 79, 4560 .

5. Herbert, A.; Alfken, J.; Kim, Y.-G;; Mian, I. S.; Nishikura, K.; Rich, A. Proc. Nall Acad. Sci. USA 1997, 94, 8421 .

6. (a) Kim, Y.-G.; Kim, P. S.; Herbert, A.; Rich, A. Proc. Natl. Acad Sci. USA. 1997, 94, 12875. (b) Berger, I.; Winston, W; Manoharan, R.; Schwartz, T.; Alfken, J.; Kim, Y.-G.; Lowenhaupt, K.; Herbert, A.; Rich, A. Biochemistry 1998, 37, 13313. (c) Schwartz, T.; Lowenhaupt, K.; Kim, Y.-G.; Li, L.; Brown, B. A. II; Herbert, A.; Rich, A. J. Biol. Chen. 1999, 274, 2899. (d) Kim, Y.G.; Lowenhaupt, K.; Maas, S.; Herbert, A.; Schwartz, T.; Rich, A. J. Biol. Chem. 2000, 275, 26828. (e) Brown, B. A. II; Lowenhaupt, K.; Wilber, C. M.; Hanlon, E. B.; Rich, A. Proc. Natl. Acad. Sci. USA 2000, 97, 13532. (1) Kim, D. J.; Oh, D.-B. Lee, S. M.; Choi, I. S.; Kim, Y.-G. Btill. Korean Chem. Soc. 2004, 25. 1430. (g) Ha. S. C.; Lokanath. N. K.; Quyen, D. V.; Wu. C. A.; Lowenhaupt, K.; Rich, A.; Kim, Y.-G.; Kim, K. K. Proce Natl. Acad. Sci. USA 2004, 101, 14367. (h) Ha, S. C.; Lowenhaupt, K.; Rich, A.; Kim, Y.-G.; Kim, K. K. Natme 2005, 437, 1183.

7. (a) Schroth, G. P.; Chou, P.-J.; Ho, P. S. J. Biol. Chem. 1992, 267, Il 846. (b) Champ, P. C.; Maurice, S.; Vargason, J. M.; Camp, T.; Ho, P. S. Nucleic Acids Res. 2004, 32, 6501.

8. Liu, R.; Liu, H.; Chen, X.; Kirby, M.; Brown, P. O.; Zhao, K. Cell $2001,106,309$.

9. Walker, G. T.; Aboul-ela, F. J. Biomol. Struct. Dy; 1988, 5, 1209.

10. Fuertes, M. A.; Pérez, J. M.; González, V. M.; Alonso, C. J. Biol. Inorg. Chem. 2001, 6,675.

I1. Schwartz, T.; Rould, M. A.; Lowenhaupt, K.; Herbert, A.; Rich, A. Science 1999. 284, 1841 .

12. (a) Herbert, A.; Schade, M.; Lowenhaupt, K.; Alfken, J.; Schwartz, T.; Shlyakhtenko, L. S.; Lyubchenko, Y. L.; Rich, A Nucleic Acids Res, 1998, 26, 3486. (b) Kim, Y,-G.; Lowenhaupt, K.; Schwartz, T.; Rich, A. J. Biol. Chem. 1999, 274, 19081.

13. Jovin, T. M.; McIntosh, L. P.; Arndt Jovin, D. J.; Zarling. D. A.; Nicoud, M. R.; van De Sande, J. H.; Jorgenson, K. F.; Eckstein, F. J. Biomol. Struct. Dyn. 1983, 1,21 .

14. Kagawa, T. F.; Howell, M. L.; Tseng K.; Ho, P. S. Nucleic Acids Res. 1993, 21, 5978. 